\title{
Utilization of Smartphone Literacy in Learning Process
}

\author{
${ }^{1}$ YENNI YUNIATI, ${ }^{2}$ ANI YUNINGSIH \\ 1,2 Fakultas Ilmu Komunikasi, Universitas Islam Bandung, Jalan Tamansari No 1 Bandung 40116 \\ Email: ${ }^{1}$ yenniybs@yahoo.co.id; ${ }^{2}$ yuningsihani@yahoo.com
}

\begin{abstract}
The utilization of smartphones is increasingly developing among the students. It causes various modifications of attitude and behavior, that media literacy nowadays becomes highly important. Therefore, media literacy shall become the priority for related parties specifically parents and teachers. In addition to helping to find information and to conduct fast communication, smartphone is also functions in formal learning process among the students. The aim of this research is to acknowledge the utilization of smartphones in formal learning process. This study uses qualitative descriptive method which makes serious efforts in describing and depicting utilization of smartphones in learning process among Junior High School students in Bandung. The research result shows that smartphones may function as a device to channel messages and to stimulate the mind, feeling and desire of the students which may encourage learning process in them and to give positive values and to bridge media literacy among the students.
\end{abstract}

Keywords: smartphone, student, learning process

\section{Introduction}

Media literacy is an increasingly popular term in Indonesia to call various activities related with critical stance towards the media. McCannon defines media literacy as the capability to effectively and efficiently understand and use mass communication (Strasburger\& Wilson, 2002). Another expert James W. Potter (2005) defines media literacy as a perspective device where humans actively empower themselves in interpreting messages they receive and in anticipating those messages. One of the popular definitions states that media literacy is the capability to access, analyze, evaluate and communicate the content of media message. From the definitions we can understand that the main focus relates with the content of media message.

Smartphones are no longer unfamiliar for both teenagers and adults. Smartphones, with all their attractive features such as online games, are highly favorable by the teenagers. Every day they communicate via their gadgets, and it is even become the first thing to grab when they wake up in the morning just to check messages from their friends. Nowadays teenagers are seemed to be doctrine by gadgets: they even seem to be "autistic" and individualist.

Kuswarno in the scientific oration of the $11^{\text {th }}$ Lustrum of the Faculty of Communication of Padjadjaran University on September $28^{\text {th }}$ 2015 declares that: "Young ages ranged from 12 to 34 years dominate the utilization of internet $(58.4 \%)$. The target for internet market is $70 \%$ aiming those under 34 years old" (Kuswarno, 2015).

Based on the result of "on Device Research" (2013), "Most Indonesian people use mobile phones while they feel lonely. However, they tend to use mobile phones on their bed $(69 \%)$, while waiting for someone/ something (35\%), while watching TV (29\%), while hanging out with family $(17 \%)$, while driving $(14 \%)$, while participating in a meeting/college $(6 \%)$ and while in the bathroom (6\%)" (Kuswarno, 2015).

Utilization of smartphones is increasingly developing among teenagers, which causes various modifications in their attitudes and behaviors. Teenagers prefer to communicate more with their friends who are in the same mobile group than with any friend who is

Received: October 27, 2016, Revision: February 16, 2017, Accepted: May19, 2017

Print ISSN: 0215-8175; Online ISSN: 2303-2499.

Accredited by DIKTI. SK Kemendikbud, No.040/P/2014, valid 18-02-2014 until 18-02-2019, Indexed by DOAJ 
physically near. Some people believe that smartphones "bring the distance friends closer and push the close friends away." The dynamics of smartphones have become primary requirements in entwining fast communication among the teenagers. Smartphone is one of the communication technologies helping people to obtain information fast. In addition to helping to find information and to conduct social communication fast, smartphones also function to develop unique communication patterns among the users, specifically teenagers.

The motives of teenagers using smartphones are for socialization, making friends, opening their insights, proving their existence and in order to keep the flow in discussing actual topics among teenagers. Based on research in the first year, most students use smartphone because it facilitates them in communication. The self-concept of State-JHS (Junior High School) students in Bandung tends to change or be transformed in social communication through smartphones. In addition to the utilization of smartphones to facilitate the teenagers to communicate, it also has the function to form self-concept, self-existence, to develop relation and obtain happiness, and the function of expression.

The advancement of technology impacts on innovations, and also changing many aspects in human activities. One of those aspects is communication. In their daily lives, humans will surely communicate, and along with the development of technology, there will be new methods of communication. In addition to be used for telephone and short message such as the other common telephones do, the facility and convenience in smartphones attract the teenagers to use them.

One of the features becoming the superiority of smartphones compared to the other cellular phones is the numerous features available, which makes Smartphones having a quite high attraction. Among them are chatting facilities or short chat facilities such as Whatsapp, Line, Path, Twitter, Instagram, Snapchat, Telegram and others. Other facilities in smartphones are push e-mail, browsing, entertainment such as music player or video player, camera and also data storage capability.

The research on smartphone utilization on students of State-JHS shows that there is fact that teenagers use smartphones because of the factor of requirement and lifestyle.
The requirement on information in the global world has encouraged the students to use smartphones. Whereas the social impact of smartphone utilization on students consists of positive and negative impacts (Yuniati, et.al., 2015). The positive impact of smartphone utilization is to improve self-esteem, to facilitate communication and to have more friends. Utilization of smartphones among JHS teenagers make them easily expressing themselves to communicate with their peers. However, the negative impact of smartphone users is that there is a tendency of internet addiction, which causes them to forget time and addiction of online games, chatting and other internet facilities which may trigger the children to become lazy and unwilling to conduct other social activities.

The other motives of teenagers to use smartphones are for self-socialization, to interact, to open insights, to gain selfexistence and to be able to join conversations on actual topics among teenagers. The research of self-concept of State-JHS (Junior High School) students in Bandung towards smartphone utilization shows that most students use smartphones because it can facilitate them in communicating. In addition to such reason, smartphone utilization can facilitate teenagers in communicating because it has the functions of the formation of selfconcept, self-existence, to build relation and obtain happiness, and the function of expression.

Smartphone utilization functions as an aid in formal learning process at schools. Education is basically a conscious and planned effort to realize learning atmosphere and learning process in order for the students to actively develop their self-potentiality to have the power of religious spiritualism, self-control, personality, intelligence, noble character and skills they will need. Formal education is an education established at schools in common. This line of education has clear educational levels, starting from elementary education, secondary education, and high education.

Education aid means a tool which may facilitate the submission of learning or teaching materials. Such aid is often being called props because it functions to help and to demonstrate something in the learning process. The props are constructed based on the principles that existing knowledge on each person shall be accepted or caught by the five senses. 
This research is aimed to analyze the smartphone utilization in formal learning process in schools which may give positive values to students and to bridge media literacy among the students. Based on the above description, this research may be formulate as: "How do smartphones being utilized by students of Junior High School in Bandung as a tool for the process of formal learning"?

\section{Theoretical Review/Concept}

Humans will search for information in any method they want and like, where one of the methods of fulfillment would be by using various media, such as mass media or social media. Satisfaction will arise when they successfully obtained the information they want to acknowledge. Based on the characteristics, information consists of: relevant and irrelevant information; useful and useless information; timely and untimely information, and valid or invalid information (Widjaja, 2010:30).

A person's curiosity arises because the person always wants to improve his or her knowledge, therefore deliberately or not, people will need and look for information to meet the curiosity. Belkin in Widjaja (2010) states; "requirement of information occurs when someone realizes there is inadequacy in the knowledge level on the situation or certain topic and there is willingness to overcome such intention". Based on the various information obtained along with the experience during interaction, a student will form his or her self-concept which will form his or her motives and attitudes in behaving. The existence of numerous social network media exist with various characteristics in terms of amount and users have become part of the students' lives. The social network often used as communication tools are: Line, Instagram, Path, Snapchat and Game.

The initial survey conducted by researchers in early March 2012 shows that almost $75 \%$ of Elementary School students, from state or private schools in Bandung, have utilized BlackBerry (BB). When the researchers survey qualitatively towards JHS and HS students, related with the intensity of the utilization of $B B$, more than $50 \%$ of the students use BB all the time, except for school hours. They admit that if they do not bring their BB with them, they feel as if something missing. The data shows that BB has become their lifestyle (Yuniati, 2013).
Previous researchers on teenager's self-concept in social communication through smartphones have proven than there is transformation of the students' self-concept to a positive way in social communication through smartphones (Yuniati and Yuningsih, JurnalMimbarL 2015, 439-450). One of the superior features of smartphones compared to other cellular phones is the numerous features available, which makes smartphones quite attractive. For example, chatting facilities or short message facilities through WhatsApp, Line, Path, Twitter, Instagram, Snapchat, Telegram and others. Other facilities in smartphones include push e-mail, browsing, entertainment such as music or video player, camera and also capability of data storage.

The positive impact of smartphone utilization is to improve self-esteem, to facilitate communication and to have more friends. Utilization of smartphones among junior high school students make them easily expressing themselves to communicate with their peers. The motives of teenagers using smartphones are for socialization, making friends, opening their insights, proving their existence and in order to keep the flow in discussing actual topics among teenagers. The self-concept of junior high school students in Bandung on the utilization of smartphones, based on research, is that most of the students use smartphones with the reason to facilitate communication.

\section{Learning Media}

The word 'media' originates from Latin word and is a plural form of the word 'medium', which literally means intermediary or agent. Method means the intermediary or agent of message from sender to receiver. Gagne (in Azhar, 2000) states that media is the various types of components in the students' environment which may stimulate them to learn. Meanwhile Briggs (in Azhar, 2000) assumes that media is the various physical tools which may present the messages and stimulate the students to learn. Books, movies, cassettes, slides are some of the examples. Media is the forms of communication, whether printed or audiovisual and its equipment. Media are able to be manipulated, visible, hearable and readable. Of any limits given, there shall be similarity among them, namely that media is anything which can be used to channel messages from sender to receiver that may stimulate the mind, feeling, interest, and attention of the students in such a way that 
the learning process would occur.

In order to understand the definition of media literacy even deeper, we must firstly understand that there are seven main elements within. The main elements in media literacy are: 1. (A) consciousness of the impact of media towards individuals and the society; 2. An understanding on the process of mass communication; 3. Development of strategies used to analyze and discuss media messages; 4. An awareness on the content of media as a 'text' which gives insights and knowledge into the human contemporary culture and the human self; 5 . Improvement of pleasure, understanding and appreciation towards the content of media (Silverblatt, 1995).

Based on the definition and main elements of media literacy as stated above, we can classify the various types of media literacy. First, based on the aimed media, media literacy consists of: literacy, media literacy (in narrow meaning) and new media literacy. Second, based on the proficiency level intended to be shown by media literacy, it can be divided into elementary, intermediary and advanced levels. The elementary level in media literacy is usually a media introduction, specifically the positive and negative effects which may be potentially given by media. Intermediary level of media literacy is aimed to develop proficiency in understanding messages. Moreover, media literacy based on the location of activities it conducted would at least be shown in three locations, namely at home/residence, school and community groups.

Utilization of smartphone literacy is highly required in order for the students to be intelligent. Students must have the capability to access, analyze, evaluate and communicate the messages, therefore they can select which message is good and which is bad.

\section{Definition of Smartphone}

Smartphone is a cellular phone with high rate of capability, sometimes with functions similar to those of a computer. There is not yet any factory standard which determines a definition of smartphone. To some people, smartphone is a telephone which works using the entire operating system software which provides standard and fundamental relation for application developer. To others, smartphone is only a telephone providing sophisticated features such as email (electronic mail), internet and the capability to read electronic book (e-book), or there is keyboard (whether builtin or external) and VGA connector. In other words, smartphone is a mini computer having the capability of a telephone (Wikipedia, uploaded on 26 October 2016).

From the searches of various literatures and journals on media literacy, we can understand that the initial of the development of media literacy is divided into two: those who believe that media impact may be harmful to the public especially the children; and those who are 'just' review the media content (Marten, 2010).

Parents or teachers group observes that the interaction and consumption pattern of smartphones utilization among students shows a quite high intensity and lack of control, and notice that the content of smartphones consumed by students are not adequately safe for their psychological development. The numerous adult materials, lifestyle offered by media in a highly persuasive method, tempting advertisements and various materials which are considered to not yet be properly consumed by students. Moreover, the time spent to access and to consume smartphones in approximately seven hours per day, shall be a tremendous and useless waste of time.

In order to respond to such symptoms, the various activities conducted would make its best efforts to suppress the negative impact as small as possible by strengthening and advising the parents, teachers and the students themselves. The step is conducted by the parents or teachers who are aware on the threats of smartphones utilization in the context to protect themselves from the negative influence given by media.

Smartphone literacy in this research relates more to the monitoring function by teachers in schools towards smartphone utilization. For example, as expressed by a media observer: In "media literacy", active audience is not just an observer or supervisor, but is active in conducting something if mass media is diverted. Such diversion may concern with wrong information, less precision of information, imbalanced information and the likes. If such things occur, the audience may protest them. Furthermore, Mulyana identifies that there is audience who is passive towards the media content and audience who is active in criticizing media content. He names the second audience as "media literate" audience (Mulyana, 2002). 


\section{Research Methodology}

This research uses qualitative descriptive method which gives its best efforts to describe and depict smartphone utilization among junior high school students in formal learning process. Whereas the approach of this research is descriptive. The qualitative descriptive research used in this research is intended to obtain information on the participation of junior high school students in Bandung in smartphone utilization as the formal learning process intensively and comprehensively. Moreover, qualitative approach is expected to reveal the situation and problems faced in smartphone utilization performed by the students.

The informants in this research are selected purposively based on certain objectives, as stated by Creswell (1994) that "sampling technique in qualitative research is more of being based on certain grounds or considerations (purposeful selection) pursuant to the research objective". Informants in this research are Junior High School students in Bandung with several criteria stipulated by the researchers in order for the collected data to be able to support comprehensive discussion and conclusion, which have used smartphones for at least one year in order to be able to reveal smartphone utilization in formal learning process. The selected informants are also students who often utilize smartphones as an aid for their school tasks.

The data in this research is information submitted by the research subject, namely the informants. Research informants are the main component in a research, because they give a profound information concerning smartphone utilization in formal learning process.

\section{Analysis Result}

Advancement of technology can now be easily enjoyed by adults and children as well. It gives various conveniences for societal lives in all sectors, one of them is smartphone utilization in education. The presence of smartphones becomes the alternative for the limitation of learning sources for teachers and students. If long ago learning sources only centered on printed books with limited amount, now the limitation may be overcome by e-book feature in smartphones. Various books as learning sources for teachers and students can now be downloaded easily.

In addition to e-books, other learning source is the internet. The convenience to access internet through smartphones makes the teachers and students capable to explore the world of science deliberately with various applications to support learning. For example, mobile education application, which is a mobile-based learning media (smartphone and tablet) and applications which supporting the tasks of the teacher.

Smartphones give benefits in learning process. Some informants state that "we have implemented e-learning at school". Some teachers have taught the students to study learning materials by visiting a website made by the teachers and do school tasks on online basis. The students also reveal that they are suggested by the teachers to use their smartphones in finding out the matters on the internet, in this matter by Google, if they have difficulties or have not understood yet about the material given at school.

According to the students, numerous advantages can be obtained by using smartphones. For example, real time communicating or connecting with people can be done easier and faster. They perform it by using various application features in the smartphones. Through smartphone utilization the students can work on their tasks precisely and faster, because there is a search engine which would help them easily find what they want to know. Therefore the students believe that by using smartphones their learning activities in searching for information for their school tasks can be more effective and efficient.

Bunga (one of the respondents) narrates that sometimes she uses smartphones to do her school tasks; smartphones can help her improving the learning process, although there are hindrances sometimes" (Interview:2016).

Furthermore, Resty (other informant) reveals "smartphone utilization may help us in understanding English. For example, when they have English task, they use smartphones by using Google Translate in their smartphones (Interview:2016).

Moreover, smartphones can also stimulate emotion when a teacher informs the students of tsunami directly, and then when they can not imagine it right, they believe smartphones can help them showing such event through applications, such as YouTube, which facilitates them to see something more real since it can be seen directly and make them understand more on anything they want to know. 
Smartphones can sometimes increase interactive, attractive or variative power but smartphone is not continuously used in various learning processes. Not all of the teachers take benefit from smartphone utilization of the students to be used in searching for tasks or knowledge, they only use it occasionally.

Based on interviews with the junior high school students in Bandung, it is found out that smartphone utilization has not yet reached maximum use. It is even not commonly used in formal learning process by the teachers in school, unless for specific subjects such as Information Technology (IT), English, or browsing for certain subject tasks. However, the government of Bandung City enacts obligation for schools to conduct mid-semester tests or semester tests online, in order for the system and learning method to be gradually changed into IT-based. In detail the findings of research on smartphone utilization in formal learning process in schools in Bandung City can be described as follows:

Referring to the above categorization table, we can observe that some schools, teachers, and Junior High School students have utilized smartphones in formal learning process in schools, some have implemented e-learning methods although some have not yet, some have used e-books as demanded by KURTILAS (the 2013 curriculum) and some have not, some have used internet-searching method in working on school tasks, and only a small number who has not performed it routinely. However, with the obligation of online UTS and UAS by the government of Bandung City, junior high schools in Bandung will automatically get used to use smartphones, for practicality.

On the benefits of smartphones in

Table 1

Data Categorization of Smartphone Utilization in Formal Learning Process in the Student's Perspective

\begin{tabular}{|c|c|c|c|c|}
\hline No & $\begin{array}{l}\text { Respondent's } \\
\text { Name }\end{array}$ & $\begin{array}{l}\text { Smartphone Utilization Method } \\
\text { in Formal Learning }\end{array}$ & $\begin{array}{l}\text { Most Supportive } \\
\text { Features }\end{array}$ & Intensity \\
\hline 1. & Bunga & $\begin{array}{l}\text { - Implementing e-learning } \\
\text { - Viewing learning material through } \\
\text { websites made by the teacher } \\
\text { - Working on tasks online }\end{array}$ & $\begin{array}{l}\text { - Website } \\
\text { - Blog } \\
\text { - Email }\end{array}$ & Occasionally \\
\hline 2. & Adinda & $\begin{array}{l}\text { Smartphones are used to search for } \\
\text { school tasks }\end{array}$ & Website & $\begin{array}{l}\text { Occasionally and } \\
\text { individually }\end{array}$ \\
\hline 3. & Adila & $\begin{array}{l}\text { - Online exercises through Edmodo } \\
\text { application } \\
\text { - Searching for materials to work on } \\
\text { each tasks }\end{array}$ & $\begin{array}{l}\text { - Website } \\
\text { - Journal }\end{array}$ & $\begin{array}{l}\text { Periodically for } \\
\text { exercises and } \\
\text { occasionally for } \\
\text { task searching }\end{array}$ \\
\hline 4. & Resty & $\begin{array}{l}\text { - School imposes online UTS and } \\
\text { UAS } \\
\text { - Some teachers give tasks to search } \\
\text { for materials on the internet }\end{array}$ & Internet & $\begin{array}{l}\text { - Obligatory } \\
\text { online UTS } \\
-\quad \quad \text { Occasional } \\
\text { searching for tasks }\end{array}$ \\
\hline 5. & Syifa & $\begin{array}{l}\text { - School imposes online UTS and } \\
\text { UAS } \\
\text { - Facilitate the searching for } \\
\text { material tasks which is not yet } \\
\text { comprehended } \\
\text { - Some teachers give them tasks } \\
\text { to search for the materials on the } \\
\text { internet }\end{array}$ & $\begin{array}{l}\text { - Internet } \\
\text { - Edmodo }\end{array}$ & $\begin{array}{l}\text { Routine and } \\
\text { periodic UTS } \\
\text { and UAS online, } \\
\text { exercise and } \\
\text { frequently if there } \\
\text { is tasks to discuss }\end{array}$ \\
\hline 6. & Rafi M Akbar & $\begin{array}{l}\text { - Smartphones are used for } \\
\text { e-learning } \\
\text { - Online UTS and UAS } \\
\text { - Searching for tasks } \\
\text { - Calculator is used in mathematics }\end{array}$ & $\begin{array}{l}\text { - Internet } \\
\text { - Calculator } \\
\text { - Google }\end{array}$ & $\begin{array}{l}\text { Routine and } \\
\text { periodic online UTS } \\
\text { and UAS, exercise } \\
\text { and frequently if } \\
\text { there is tasks to } \\
\text { search for }\end{array}$ \\
\hline 7. & $\begin{array}{l}\text { Fatimah } \\
\text { Azzahra }\end{array}$ & $\begin{array}{l}\text { - Online UTS and UAS } \\
\text { - Task searching is more comfortable } \\
\text { using laptops } \\
\text { - No e-learning yet }\end{array}$ & Internet & $\begin{array}{l}\text { Rarely used except } \\
\text { for online UTS and } \\
\text { UAS }\end{array}$ \\
\hline
\end{tabular}

Source: Research Result (2016) 
learning process, they state that "in [our] school, we have performed it. "As the example of what has been revealed in their learning process at school, some teachers have taught the students to view learning materials by visiting a website they have made and also working on tasks online. The students also stated that the teachers have suggested them to use their smartphones to overcome difficult tasks or material which they have not comprehended yet and look for them on the internet.

According to the students, there are numerous advantages that can be obtained from smartphone utilization. For example, it would easier and faster for us to communicate or connect with distant friends or relatives in real time. It can be done through various application features in the smartphone such as BBM, Line, Instagram, or other social media. By using smartphones, working on tasks can be conducted precisely and faster, because there are search engines which are easy to use and anything we want to acknowledge will be displayed on Google services. Therefore, the teenagers consider that smartphones can help their learning activities in searching for information for their school tasks to be more effective and efficient.

According to Adila and Resty, not all of the teachers benefit smartphones in formal learning: "well, there are some teachers who told us to use smartphones, but most of them don't. They do it only for task searching and performing online UTS and UAS" (interview in 2016). However on the other side, the students realize the importance of searching to understand more on the subjects which are difficult to understand in the classroom.

The students reveal the obstacles in using smartphones in formal learning process: "...sometimes while using smartphones for school tasks, we can't control ourselves that we feel hampered by the social media features which make us less focus on what we are actually doing because social media is highly fun and we love to chat that sometimes it bothers us while working on the tasks" (interview with Fatimah, 2016).

Meanwhile according to the teachers, smartphones are not too influential in class activity, that if smartphones are not used in class for social media, students will still use their time to be active in class. Therefore, according to the JHS students, smartphone can help them in improving their learning process, although sometimes it may distract them.

In the teachers' perspective, smartphone is actually useful to facilitate and for the effectiveness of teaching, although sometimes it can be difficult to monitor because there must be a specific controlling system and program. The following is the result of smartphone utilization research in formal learning.

\section{Discussion}

Nowadays most teenagers use smartphone as media of communication. Smartphone become a vital tool and must be carried anywhere. Teenagers who are psychologically unstable and are still looking for their identity are delightful in showing off their existence in social media. It can be proven by the great amount of teenagers in Indonesia having more than one social media account. Most of the teenagers in Indonesia have Line, Twitter, BlackBerry Messenger (BBM), Instagram, Path, Snapchat accounts and other social media accounts.

The fun of interaction in the virtual world often makes its users to utilize the virtual world more than to directly interact. It often occurs that while hanging out with friends or family, many people tend to 'have fun' with their own smartphones. It makes the teenagers love to live in the virtual world compared to the real world. As the consequence, real social interaction becomes rarely being conducted and becomes more individualist. In reality, humans are social creatures who cannot live solely; individualism may decrease empathy which may give impact on the loss of togetherness and the feeling of being in the same boat.

From the interview with the students, they say that they use smartphones in their various daily activities, whether during studying or connecting with others. They have also understood that there are impact of both positive and negative. The students are aware that using social media is a way of communication with their environment.

Most of the students understand media literacy, namely to analyze and discuss a message content. They use smartphones as a way to utilize media in a smart manner and to acknowledge on how to use media as best as possible.

It is very important to acknowledge the benefit of smartphones, especially for students in supporting their learning activities. 
In fact, talking about positive and negative impacts, any aspects in life must have both positive and negative impacts. But it is all up to each of the individuals on how to use it wisely and take benefit from it. Common people or parents in the rural areas believe that internet is identical with negative things. Most of them prohibit their children to access the internet.

The benefits of internet for students and education are to expand the insights and knowledge, as an additional source of learning materials which are not yet comprehended in school, and a training tool for students to acknowledge smartphone utilization methods. Learning media is a media specifically designed to optimize the learning process. Learning media is now designed to be IT-based, so as smartphones can also be engineered into effective and efficient learning media. However, to perform such thing requires regulation, system and program which technically would regulate smartphone utilization in such a way that it still keeps the flexibility and attractiveness. It can also conduct adequate monitoring, control, and supervision to the students in the utilization mechanism. In order to realize the idea above, the schools can cooperate with expert consultants of information technologybased system.

There are several objectives in using learning media, such as to facilitate learning process, improving learning efficiency, maintaining relevance with learning objectives, helping the students to concentrate. According to Gagne; "It is a learning source component which may stimulate the students to study". According to Briggs; "It is a physical device containing instructional materials". According to Schramm; "It is information or instructional message-bearer technology". According to $Y$. Miarso; "It is anything which may stimulate students' learning process."

\section{Conclusions}

Communication technology may help human's life in terms of being used in accordance with its function, namely as media of education to be utilized in learning process in the classroom between the students and the teachers. Smartphone utilization, such as the internet, inside and outside the schools would become the most vital support in the realization of learning and teaching process effectively. Moreover, smartphone utilization can help the students, accessing and even expanding the learning sources, and also enhance communication between teachers and students, parents and among fellow students. Smartphones have advantages of displaying texts, images, voices and movements. Based on the above description, it is concluded that smartphones may function as an aid in learning process and facilitate the students in working with their school tasks.

Smartphone utilization in formal learning process has not yet been optimized, and there are also gaps in the utilization activities by the students and teachers. There are only certain teachers who have used e-learning, e-book and website through smartphones in their learning process in the classes. However the activities which have been conducted by all regarding the use of technology are online UTS (mid semester test) and UAS (final test) as they are obliged to do by the government of Bandung City. Most of the students use smartphones to access task materials individually or in groups. School tasks which structurally performed through smartphones are still limited. Although the teachers realize and support the students to utilize smartphones as part of the learning process, they are still worried on the difficulties in monitoring and controlling the students.

Teachers and parents are expected to engage with recent technology and be smarter as/than the students in order to be able to monitor and acknowledge anything the students have conducted with their smartphones. That way they will be able to monitor and limit the excessive smartphone utilization.

Students are expected to utilize smartphones wisely, because the more sophisticated and advanced communication technology are, we have to be smarter in using them to help us improve learning quality, to concentration more. and also to socialize well.

\section{References}

Azhar, A. (2000). Media Pengajaran. Jakarta: PT Raja GrafindoPersada

Creswell, J. W. (1994). Research Design: Qualitative and Quantitative Approaches. Westport, CT: Praeger Publishers.

Kuswarno, M.S., Prof. H. Dr. Engkus. (2015). Potret Wajah Masyarakat Digital Indonesia. Orasi Ilmiah Pada Dies Nataliske - 55 tas Ilmu Komunikasi Universitas Padjadjaran, 28 September 2015. Bandung :UniversitasPadjadjaran. 
Mulyana, D. (2000). IImu Komunikasi, SuatuPengantar. Bandung: Rosdakarya. Widjaja, H.A.W. (2010). Komunikasi, Komunikasi \& Hubungan Masyarakat.
Jakarta: Bumi Aksara.

Yuniati, et. al. (2015). Jurnal Mimbar Volume 31 , No. 2 Tahun 2015, hal439 - 450. 